\begin{tabular}{|c|c|}
\hline \multirow{3}{*}{ 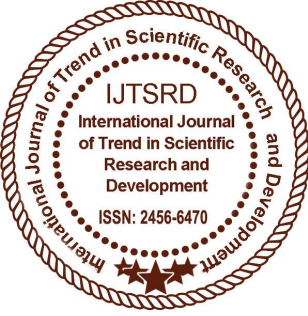 } & $\begin{array}{l}\text { International Journal of Trend in Scientific } \\
\text { Research and Development (IJTSRD) }\end{array}$ \\
\hline & International Open Access Journal \\
\hline & ISSN No: 2456 - 6470 | www.ijtsrd.com | Volume - 2 | Issue - 4 \\
\hline
\end{tabular}

\title{
Teacher Awareness of Assessment Strategies Used in Inclusive Classrooms and Actual Practices of Inclusiveness. A Case Study of Public Primary Schools in English Speaking Cameroon
}

\author{
Bansir Felicitas Asoh \\ Department of Curriculum Studies and Teaching, Faculty of Education, University of Buea, \\ Cameroon, Central Africa
}

\section{ABSTRACT}

The study sought to explore teachers knowledge of the various assessment strategies used in inclusive classrooms and the actual practices of inclusiveness in Cameroon public primary schools. International and national policies and regulations suggest inclusive practices in response to international declarations and conferences calling on school systems to be inclusive. The implementation of such changes in regular classrooms rest on teachers. Among other factors which may make inclusion effective, teachers awareness of the assessment strategies used in inclusive classrooms is significant. Equally, the Cameroonian educational system is test and examination oriented wherein progress and promotion depends on scores and grades. A questionnaire and an observation guide was used to collect data for the survey. 360 public primary school teachers were randomly selected from eight Division in the two English Speaking Regions of Cameroon. 37 classes were observed in the same Divisions (mostly inclusive model schools). Findings revealed that public primary school teachers are not aware of the assessment strategies used in inclusive classrooms. Implications and recommendations are discussed.

Keywords: awareness, inclusive education, regulations, assessment strategies

\section{INTRODUCTION}

Inclusive education has been internationally recognized as a philosophy for attaining equity justice and quality education for all children especially those who have been traditionally excluded from mainstream education for reasons of disability, ethnicity, gender or other characteristics. Inclusive education has increasingly become the focus of debate in discussions about the development of educational policy and practice around the world (Farrell and Ainscow, 2002). The education of children and young people with special educational needs (SEN) is now an established key policy objective in many countries of the world (Lindsay, 2007). There is increased awareness of differences in access to and outcomes of education throughout the world. This has implications regarding the power of education to reduce poverty, improve the lives of individuals and groups, and to transform societies (Gubb \& Lazerson, 2004).

United Nations Economic Social and Cultural Organization (UNESCO) (2005) defines inclusive education as a process of addressing and responding to the diversity of needs of all learners, through increasing participation in learning, cultural activities in communities and reducing exclusion within and from education. It involves changes in strategies, with a common vision which covers all children at the appropriate age range with the conviction that it is the responsibility of the regular school system to educate all children. According to the Organization fo Economic Co-operation and Development (OECD) (2010), inclusive education is concern with provision of support services to learners with diverse categories of special educational needs.

Looking at the Cameroonian school system test and examinations are key to progress or promotion. 
Equally, some of the regulations on inclusive education have specified how public examinations should be conducted as concerns children with special educational needs, meanwhile at the primary (basic) level much have not been done as concerns classroom evaluation which poses a question as to whether the teachers know the evaluation strategies used in inclusive classrooms, and what they actually do when evaluating pupils with special educational needs in their classes.

\section{BACKGROUND}

The fundamental principle of inclusive education as specified in the Salamanca Statement and Framework for Action on Special Education (1994) states that 'all children and young pupil, with and without disabilities or other special needs, are learning effectively together in ordinary mainstream schools, with appropriate networks of support'. In paragraph three, it goes on to state that 'schools should accommodate all children regardless of their physical, intellectual, social, emotional, linguistic or other conditions'. This should include disabled and gifted children, street and working children, children from remote or nomadic populations, children from linguistic ethnic or cultural minorities and children from other disadvantaged or marginalized areas or groups (UNESCO, 1994).

While inclusive education have been successfully implemented in many countries, others especially in Africa are still in the process of achieving this goal. Findings across the African continent regarding the capabilities and competencies of the school teachers show that, most are struggling to respond to the wide range of diversity of students found in their classes (Endeley 2013). Meanwhile the role of the general education teacher has demanded an increase understanding of types of disabilities, types of appropriate curricular and instructional modifications, activity differentiation and interaction with students with special educational needs in the classroom (Raymond 1995).

The development of the field of special education has involved a series of stages during which educational systems have experienced difficulties in teaching and learning due to the fact that the environments are not conducive. There is often the lack of resources and the teachers are not also equipped with the necessary skills. The emerging critical issues that need to be addressed concerning inclusive education in
Cameroon in particular, and Africa in general are centered on classroom practice, teacher education, parental involvement, infrastructure, curriculum and policy (Tchombe, 2014).

Although there are international policies and national regulations advocating for all children to be admitted in schools, Tchombe, (2014) is of the view that there are limitations in specifications orienting practice that make efforts to implement such policies and regulations difficult. Lupart (2002) provided information putting the situation in to perspective by arguing that government policies that refer to establishing rights but which do not provide the means of enforcing them are not only meaningless, but also dishonest as they give the impression that they are rights, when in fact, they are not. Meanwhile Wolff (2003) noted that students with disabilities have been moved into regular classroom without ensuring adequate teacher training or support. Equally the ill preparedness of teachers is because teacher training in some cases, focuses on curricular subjects rather than generic pedagogical skills, capacity for critical thinking and creativity (Topping and Maloney 2005).

In Cameroon the concept of special education officially known as 'education for the handicapped' refers to educational and social services for people with only some categories of special needs (disabilities) like the blind, deaf, physically disabled placed in specialized institutions or rehabilitation centers (Yuh and Shey, 2008). This is mostly at the basic education level. The Cameroon education system also faces problems of practical categorization of Special Education Needs in terms of diverse educationally relevant functional impairments like slow learners, those with behavioral problems, fast or gifted learners (Endeley, 2013).

Major efforts to educate children with special educational needs have been made mostly by religious and non-governmental organizations in specialized schools (Yuh and Shey, 2008). Schools for the deaf and schools for the blind are found in many regions in the country, such as the Rehabilitation Center for the Blind in Buea and the Saint Joseph's Children and Adult Home (SAJOCA) Bafut which caters for people with physical disabilities. With the creation of the Ministry of Social Affairs in 1975, the wellbeing of persons with disabilities was provisioned and in collaboration with the Ministry of Education has contributed to improve the education of persons with 
disabilities by authorizing the creation of many privately owned and model inclusive schools in most regions in the country.

The Cameroonian educational system is very much at the integration level but with strives towards inclusive education (Ndame, 2012). In Cameroon, the concept of inclusive education is understood and practiced differently as it incorporates academic, social, bilingual, intercultural, gender and other dimensions (Tukor, 2008; Yuh and Shey, 2008). As pointed out by Ndame, (2012) the uniqueness of the Cameroonian approach to inclusion is underpinned by multiple contextual factors such as; it's highly centralized educational system, cultural and linguistic diversity, level of economic growth and socio-historical changes in the two co-habiting Anglophone and Francophone education sub-systems. On the other hand, Tchombe, (2014) states that an understanding of the meaning and principle of inclusive education in Cameroon is necessary for the type of expectation required for effective inclusive practices, but observes that there is a complete lack of data describing inclusive education in Cameroon.

As pointed out by Endeley (2011) although Cameroon is a signatory to the international conventions and policies for inclusive education such as the word declaration on Education For All (EFA), the word conference on Special Needs Education in 1994, the United Nations Convention on the Rights of People with Disabilities in 2006 among others, much has not been done in their effective implementation. However, much has been done in terms of regulations geared towards ensuring access to education for all especially learners with special educational needs.

Law No.83/013 of $21^{\text {st }}$ July 1983 provides general dispositions and practical modalities for the protection of people with disabilities followed by its text of application put in place in law No.90/1516 of $26^{\text {th }}$ November 1990. In part one and two which focus on education, it was stated that pupils with disabilities should be allowed to repeat a class up to two times if poor performance is as a result of their situation (Cameroon, 1990).

Equally, in 1998 after the Education Forum of 1995 the educational rights of children and particularly those with disabilities was provisioned in law No.98/004 of $14^{\text {th }}$ April 1998. This law laid down guidelines for education in Cameroon and states in section 6 that, the state shall guarantee the right of every child to education (Cameroon, 1998).

Another very important law was enacted particularly to address the protection and welfare of persons with disabilities in Cameroon. That is Law No.2010/002 of $13^{\text {th }}$ April 2010. This law among many issues emphasized the provision of special education, psychosocial support, socio-economic integration, access to employment and infrastructure, housing and transport for persons with disabilities (Cameroon, 2010).

As a result of these laws the ministries involved came together and issued circular letters, some of which included No.86/L/1656/MINEDUC/CTZ of January1986 instructing school administrators to facilitate the admission of children with disabilities in their institutions. On October $11^{\text {th }} 2005$, another circular letter signed by the Minister of Secondary Education gave instructions on the management of visually impaired and hard of hearing students in the organization of public and class examination and made emphases on the availability of braille and sign language specialists in the examination centers. As for now, only the brailing of examinations is in practice (Tchombe 2014).

In addition to these in 2006, the Ministries of Secondary Education and Social Affairs sent out a joint circular letter concerning the admission of handicapped children and children of handicapped parents in secondary schools, giving them a financial waiver. Furthermore, law No.283/07/LC/MINESEC/ MINAS of $14^{\text {th }}$ August 2007 relating to the identification of children with disabilities and those born of parents with disabilities was issued. It encouraged the enrolment of these children in government colleges and their participation in official examinations (Cameroon, 2007). This limits consideration only to the visually impaired, hard of hearing and the physically impaired. All other categories of children with special educational needs were left out.

Looking at Cameroon's poverty reduction strategy paper, it specified the government effort to continue addressing the educational needs of persons with disabilities in order to reduce their dependence such as easing access to buildings as well as financial support (IMF, 2010). However Nsamenang and Tchombe (2011) stated that despite all these 
measures, access to infrastructure and partnership to enhance the attendance of school by children with disabilities still has a long way to be achieved.

\section{RESEARCH PROBLEM}

While Cameroon is making initial strides towards inclusive education practice, it is primordial to find out if the public primary school teachers has the competences for teaching in mixed ability classrooms especially when it concerns knowledge of assessment strategies. This is because underlying the process of inclusion is the assumption that the teachers has certain knowledge and understanding about the needs of different learners, learning techniques and curriculum strategies (Fullan, 1999).

One of the major objective of inclusive education is increase in access to education by a large number of pupils with special educational needs. This poses a lot of challenges to the classroom teachers who is expected to develop a different set of skills and knowledge than was the case before.

Among other factors which serve as barriers to the effective implementation of inclusive education, knowledge of assessment strategies used in inclusive classrooms need to be addressed. This is because it has an enormous implication on the progress and continuity in education by children with special educational needs. Wrong methods of assessment can lead to demotivation and eventual drop out. Thus this paper attempts to find out the extent to which public primary school teachers are familiar with the assessment strategies used in inclusive classrooms. The study was guided by one research question:

$>$ What assessment strategies do public primary school teachers use to respond to diversity in the classrooms?

\section{REVIEW OF RELATED LITERATURE}

A number of studies (Pijil\&Frissen, 2009; Kurawa, 2010; Rouse, 2009; Cusher, 2006) posits that a diversity of learners can benefit equally from examinations and test procedures used by the teacher without bias. But the most important thing in testing students with disabilities is ensuring that test results reflect their knowledge and skills, not their disabilities. Thus classroom test should be adapted in ways that helps the teacher test students with disabilities fairly and with a reasonable amount of accuracy. These studies equally showed that unfair results lead to demotivation and depression in some students with special needs.

The European Agency for Development in Special Needs Education (EADSNE), (2003) states that tests are a significant component of education because they provide information relevant to placement, instruction and future career decisions. But educational systems which over-emphasize academic achievement and competition pose a serious dilemma for inclusion. It is for this reason that Westwood, (2007) after his study of informal assessment strategies in inclusive settings states that for learners with significant learning difficulties or disabilities, it is important to recognize that progress can be achieved in many different ways apart from increase in academic knowledge or skills. Westwood discovered that successful completion of classroom and homework assignment, student's participation in class activities and attendance were amongst the strategies that carry the potential to reinforce positive behavior. He went further to state that such informal assessment have the advantage that they involve goals which are achievable by all students and do not differential between those with special needs and their typical peers.

In the study of Salend (1995) in multicultural education the researchers sampled 20 pupils from different cultural backgrounds. Using the same educational content, they set test in different formats and administered them to the sample. From the findings the researchers stated that student-centered evaluation is an important part of effective multicultural education because it takes in to account unique student perceptions and experiences. Strategies identified by the researchers include questionnaires, interviews, journal entries, learning logs, and think aloud.

Venn, (2000) conducted a focus group discussion with a group of 10 teachers in Upper Saddle River, New Jersey on assessing students with special educational needs. And found out that self-assessment and peerassessment can be fun and morale busting in inclusive classrooms. In his study Venn reported that most teachers were of the opinion that this approach is particularly relevant for students with disabilities or learning difficulties because it foster independent learning and builds confidence. But cautioned that since it involves students in assessing their peers, providing feedback and highlighting achievements, it 
needs to be carefully guided and structured. He concluded that this approach has the potential to promote successful learning and can also enhance student-teacher relationship.

Another assessment strategies that suites students with special needs is using performance assessment. In a study carried out by Scruggs, Mastropieri, Bakken and Brigham (1993) cited in Scruggs and Mastropieri 2000, students with learning disabilities performed relatively poorer on a more traditional test of their recall of vocabulary words after hands-on science instruction. However, they were much more able to demonstrate their knowledge in performance-based tests that require them to determine, for example, which of two minerals is harder, or whether a mineral contains calcite. They concluded by stating that "performance assessment is an effective way of measuring all students' comprehension of academic content in at least part of virtually all school subjects, including science, math, social studies, arts, vocational education and physical education p.389. in addition, Fuchs (1998), posits that although performance assessment may vary widely, they often have three key elements in common which benefit students with special needs; students construct their own responses, rather than selecting or identifying correct responses, teachers can observe students' performance on tasks reflecting real-world or authentic requirements, students responses can reveal patterns in students' thinking and learning as well as whether the question was correctly answered.

The study of Erickson, Ysseldyke, Turlow and Elliott (1998) found out that administering test for students with learning disabilities in bits over a period of days yielded better results than administering the same test during a set of hours. Equally Elliott, Kratoachwill, \& Schulte (1998) also found out that the performance of students with disabilities equally increased comparatively when they were tested in a distractionfree room away from their regular peers. The study equally showed that individually administered test reduces tension and motivated the students with special educational needs to perform better. This is in line with the Learning Disability Association (1993) which carried out a survey on testing strategies for students with disabilities and found out that test modifications that suite learners with special needs included an audio cassette edition of the test, extended time for taking the test, frequent breaks, and use of a private testing room.
In another study carried out in Ireland, Lerner (2003) found out that maintaining portfolios of student work have become a popular way for teachers to track students' progress and collect evidence of learning in inclusive classrooms. The teachers sampled reported that these portfolios involve collecting multiple samples of the student's work over a period of time, fully completed work or projects, or work which reflect their best effort in a key skill or subject area. Lerner then concluded by stating that the purpose of this approach is to display concrete examples of the student's progress which they can share with others and even for self-evaluation. That the approach benefit students with special educational needs who are poor test takers.

Equally Bowe (2005) carried out a case study of the use of portfolios with students with disabilities. In this study, a sixth-grade general education teacher used a portfolio to chronicle the progress of a student, 'Tom', classified as seriously emotionally/behaviorally disturbed. Tom was described as having difficulties getting along with peers and frequently fighting with them, being argumentative and non-compliant with teachers. His portfolio included a video tape of Tom's performance during cooperative group lessons, his manual projects and assignments and even outside school social activities. This was used to assess Tom's performance in certain aspects of learning. They conclude by stating that when compared with the results of written test, the portfolio gave a better picture of Tom's performance. But cautioned that while portfolios are potentially valuable evaluation tools, they should supplement, not supplant standardized achievement, psychological and curriculum-based measures.

The results of two methods of reading assessment using computer and paper and pencil are examined in a study by Horton and Lovit (1994). In one condition, students read textbooks passages presented on a computer, completed study guides and took 15 item test on the computer. In the other condition, students read passages from their test books completed study guides, and took 15 item test with pencil and paper. The 72 participant 13 with disabilities, 16 remedial and 43 normal achieving were divided in to three groups: teacher directed, dyadic and independent. Two types of test items, factual and interpretative, were examined in the study. The results of the group analysis significantly favored the computer group on factual questions for both the students with and 
without learning disabilities. Individual analysis indicated few significant differences between the two types of group reading inventories. Overall, on interpretative questions, the students with disabilities scored slightly higher with pencil and paper and the normal achieving student scored higher on computer assessment.

From empirical literature, it is seen that most children with special educational needs are poor test takers and unfair results leads to demotivation and depression. The strategies that have worked well in inclusive classrooms included; test modification/ adaption and spacing, use of information and communication technologies, portfolios and other informal strategies.

\section{METHODOLOGY}

The study was a survey of a cross sectional nature. The population consists of 9073 public primary school teachers in the 15 Divisions in the two English speaking Regions of Cameroon. Out of this eight Divisions were randomly selected. Four from each Region with a total population of 5773 teachers. Out of these 360 teachers were sample from 37 schools also randomly selected both in urban and rural areas, and a total of 325 of them completed and returned the instrument.

A questionnaire and an observation guide were used to collect data for the study. Items on the questionnaire were constructed in to two parts. The first part was the introduction, while the second part consisted of questions on a likert scale aiming at answering the research question. The observation guide also have similar items which helped the researcher to see and affirm how public primary school teachers assess pupils in inclusive classrooms. The concepts were rated as; adequate, inadequate and none. Mostly model inclusive schools were observed.

\section{DATA PRESENTATION AND ANALYSIS}

\section{Assessment strategies used to respond to diversity in inclusive classrooms}

\begin{tabular}{|c|c|c|c|c|c|c|c|}
\hline \multirow{2}{*}{$\begin{array}{c}\text { The following are Assessment strategies } \\
\text { used in Inclusive Classrooms }\end{array}$} & \multicolumn{5}{|c|}{ Stretched } & \multicolumn{2}{|c|}{ Collapsed } \\
\hline & SA & $\mathbf{A}$ & $\mathrm{D}$ & SD & $\mathrm{U}$ & $\bar{A}$ & $\mathrm{D}$ \\
\hline $\begin{array}{l}\text { I give the same test and examination to all the } \\
\text { children }\end{array}$ & $\begin{array}{l}39.2 \% \\
(122)\end{array}$ & $\begin{array}{l}33.5 \% \\
(109)\end{array}$ & $\begin{array}{l}3.2 \% \\
9)\end{array}$ & $\begin{array}{l}5.5 \% \\
(19)\end{array}$ & $\begin{array}{l}4.0 \% \\
(13)\end{array}$ & $\begin{array}{l}72.8 \% \\
(240)\end{array}$ & $\begin{array}{l}23.2 \% \\
(81)\end{array}$ \\
\hline $\begin{array}{l}\text { Some children with disabilities are tested in } \\
\text { different halls and given more time to } \\
\text { complete their tests or examination }\end{array}$ & $\begin{array}{l}17.5 \% \\
(57)\end{array}$ & $\begin{array}{l}32.6 \% \\
(106)\end{array}$ & $\begin{array}{l}30.2 \% \\
(98)\end{array}$ & $\begin{array}{l}12.9 \% \\
(42)\end{array}$ & $\begin{array}{l}6.8 \% \\
(22)\end{array}$ & $\begin{array}{l}50.2 \% \\
(163)\end{array}$ & $\begin{array}{l}43.1 \% \\
(140)\end{array}$ \\
\hline $\begin{array}{l}\text { I assess children with dis } \\
\text { portfolios instead of examina }\end{array}$ & $\begin{array}{l}16.0 \% \\
(52)\end{array}$ & $\begin{array}{l}16.5 \% \\
(52)\end{array}$ & $\begin{array}{l}26.2 \% \\
(85)\end{array}$ & & $\begin{array}{l}6.8 \% \\
(22)\end{array}$ & $\begin{array}{l}22.8 \% \\
(79)\end{array}$ & $\begin{array}{l}70.5 \% \\
(86)\end{array}$ \\
\hline Those who c & $\begin{array}{l}33.8 \% \\
(110)\end{array}$ & $\begin{array}{l}42.5 \% \\
(138)\end{array}$ & $\begin{array}{l}14.8 \% \\
(48)\end{array}$ & $\begin{array}{l}5.5 \% \\
(18) \\
\end{array}$ & $\begin{array}{l}3.4 \% \\
(11) \\
\end{array}$ & $\begin{array}{l}76.3 \% \\
(248) \\
\end{array}$ & $\begin{array}{l}20.3 \% \\
(66)\end{array}$ \\
\hline $\begin{array}{l}\text { I give prac } \\
\text { ones to som }\end{array}$ & $\begin{array}{l}6.5 \% \\
(8421)\end{array}$ & $\begin{array}{l}19.7 \% \\
(64)\end{array}$ & $\begin{array}{l}43.7 \% \\
(142)\end{array}$ & $\begin{array}{l}25.8 \% \\
(84)\end{array}$ & $\begin{array}{l}4.3 \% \\
(14)\end{array}$ & $\begin{array}{l}26.2 \% \\
(85)\end{array}$ & $\begin{array}{l}69.5 \% \\
(226)\end{array}$ \\
\hline MRS & $\begin{array}{l}24.5 \% \\
(398)\end{array}$ & $\begin{array}{l}37.4 \% \\
(607)\end{array}$ & $\begin{array}{l}21.8 \% \\
(354)\end{array}$ & $\begin{array}{l}11.3 \% \\
(184)\end{array}$ & $\begin{array}{l}5.0 \% \\
(82)\end{array}$ & $\begin{array}{l}61.8 \% \\
(1005)\end{array}$ & $\begin{array}{l}33.1 \% \\
(538)\end{array}$ \\
\hline
\end{tabular}

$\mathrm{N}_{\text {cases }}=325 ; \mathrm{N}_{\text {responses }}=1625$

Findings on assessment methods used to respond to diversity in inclusive classes revealed that the public primary school teachers are not actually aware of assessment methods used in inclusive classrooms. As can be seen on the table above, $72.8 \%$ (240) of the teachers give the same test to all the children ill respectiveof their abilities. Only fifth percent of the teachers $50.2 \% \quad(163)$ evaluate children with disabilities in different halls and give them more time to complete their test or examination. Equally only $22.8 \%$ (79)of the teachers assess children with disabilities by their portfolios instead of examinations. On the other hand,76.3\%(248) of the teachers agreed that children with disabilities who cannot write are evaluated orally and only $26.2 \%(85)$ give practical exercises instead of written ones to some children with disabilities. 
Assessment strategies based on observation

\begin{tabular}{|c|c|c|c|c|c|c|c|c|}
\hline $\begin{array}{c}\text { Divisi } \\
\text { on }\end{array}$ & School & $\begin{array}{c}\text { Locati } \\
\text { on }\end{array}$ & Class & $\begin{array}{l}\text { Written } \\
\text { test only }\end{array}$ & $\begin{array}{c}\text { Use of oral } \\
\text { test }\end{array}$ & $\begin{array}{l}\text { Use of } \\
\text { practical } \\
\text { exercise } \\
\text { and } \\
\text { portfolios }\end{array}$ & $\begin{array}{l}\text { Differen- } \\
\text { tiated } \\
\text { timing }\end{array}$ & $\begin{array}{l}\text { Differen- } \\
\text { tiated } \\
\text { examin- } \\
\text { ation space }\end{array}$ \\
\hline Fako & $\begin{array}{l}\text { GS } \\
\text { Bokwango } \\
\text { GP } 2 \\
\end{array}$ & Rural & 1 & Adequate & Adequate & Adequate & Adequate & Inadequate \\
\hline Fako & $\begin{array}{l}\text { GS } \\
\text { Bokwango } \\
\text { GP } 2\end{array}$ & Rural & 4 & Adequate & Adequate & Adequate & Adequate & Inadequate \\
\hline Momo & $\begin{array}{l}\text { GS } \\
\text { Wunfiku }\end{array}$ & Rural & 2 & Inadequate & Inadequate & Inadequate & Inadequate & Inadequate \\
\hline Ndian & $\begin{array}{l}\text { GS Lobe } \\
\text { Estate }\end{array}$ & Urban & 4 & Adequate & Adequate & Inadequate & Inadequate & Inadequate \\
\hline Ndian & $\begin{array}{l}\text { GS Lobe } \\
\text { Estate }\end{array}$ & Urban & 2 & Inadequate & Inadequate & Inadequate & Inadequate & Inadequate \\
\hline Momo & $\begin{array}{l}\text { GPS GP } 1 \\
\text { Mbengwi }\end{array}$ & Urban & 3 & None & Inadequate & Inadequate & Inadequate & Inadequate \\
\hline Mbui & GPS Tobin & Urban & 3 & Inadequate & Inadequate & Inadequate & Inadequate & Inadequate \\
\hline Mbui & GS Tobin & Urban & 5 & Adequate & Inadequate & Inadequate & Inadequate & Inadequate \\
\hline Meme & $\begin{array}{l}\text { GS } \\
\text { Kumba- } \\
\text { Mbeng }\end{array}$ & Urban & 5 & Adequate & Adequate & None & Inadequate & Inadequate \\
\hline Meme & $\begin{array}{l}\text { GS } \\
\text { Kumba- } \\
\text { Mbeng } \\
\end{array}$ & Urban & 1 & Adequate & Adequate & Inadequate & Adequate & Inadequate \\
\hline $\begin{array}{l}\text { Meza } \\
\mathrm{m}\end{array}$ & $\begin{array}{l}\text { GPS } \\
\text { Bamenda } \\
\text { Old Town }\end{array}$ & Urban & 4 & Adequate & Inadequate & Inadequate & Inadequate & Inadequate \\
\hline $\begin{array}{l}\text { Meza } \\
\mathrm{m}\end{array}$ & $\begin{array}{l}\text { GPS } \\
\text { Bamenda } \\
\text { Old Town } \\
\end{array}$ & Urban & 2 & None & Inadequate & Inadequate & Inadequate & Inadequate \\
\hline $\begin{array}{l}\text { Lebial } \\
\text { em }\end{array}$ & $\begin{array}{l}\text { GPS } \\
\text { Fontem }\end{array}$ & Urban & 6 & Adequate & Inadequate & Inadequate & Inadequate & Inadequate \\
\hline $\begin{array}{l}\text { Lebial } \\
\text { em }\end{array}$ & $\begin{array}{l}\text { GPS } \\
\text { Fontem }\end{array}$ & Urban & 1 & Adequate & Inadequate & Inadequate & Inadequate & Inadequate \\
\hline $\begin{array}{l}\text { Ngo- } \\
\text { ketunj } \\
\text { a }\end{array}$ & $\begin{array}{l}\text { GPS } \\
\text { Bamunka } \\
\text { GP }\end{array}$ & Urban & 4 & Inadequate & Adequate & Inadequate & Inadequate & Inadequate \\
\hline $\begin{array}{l}\text { Ngo- } \\
\text { ketunj } \\
\text { a } \\
\end{array}$ & $\begin{array}{l}\text { GPS } \\
\text { Bamunka } \\
\text { GP 2 } \\
\end{array}$ & Urban & 1 & Adequate & Inadequate & Adequate & Adequate & Inadequate \\
\hline \multirow{3}{*}{$\begin{array}{l}\text { Total } \\
\mathrm{N}=16\end{array}$} & \multicolumn{3}{|l|}{ Not existing } & $12.5 \%(2)$ & $0 \%(0)$ & $6.2 \%(1)$ & $0 \%(0)$ & $0 \%(0)$ \\
\hline & \multicolumn{3}{|l|}{ Adequate } & $62.5 \%(10)$ & $31.2 \%(5)$ & $18.8 \%(3)$ & $25.0 \%(4)$ & $0 \%(0)$ \\
\hline & \multicolumn{3}{|l|}{ Inadequate } & $25.0 \%(4)$ & $68.8 \%(11)$ & $75.0 \%(12)$ & $75.0 \%(12)$ & $100 \%(16)$ \\
\hline
\end{tabular}

Written tests only was not done in 2 of the 16 schools making a proportion of $12.5 \%$. The majority $62.5 \%$ (10) of the schools adequately do written tests while
$25.0 \%$ (4) did not do it adequately. As for oral test, all the school do it while less than the majority $31.2 \%(5)$ do it adequately and $68.8 \%$ (11) did not do it 
adequately. Only one school used practical exercise and portfolio, while the rest did not use the strategy at all. Concerning differentiated timing, all the schools did it, but only few $25.0 \%$ (4) did it adequately while $75.0 \%$ (12) did not do it adequately. As far as differentiated examination space was concerned, all the schools did it but inadequately.

\section{DISCUSSION}

As concerns assessment strategies used by public primary school teachers to respond to diversity in the classroom, results revealed that majority of the teachers are not aware of good practices as they still give the same test and examination to all the pupils irrespective of their disabilities. This was contrary to the finding of Scruggs and Mastropieri (1996), Baca and Almanza (1991) and Shaw \& Lewis (2005) who found out that adapting test for learners with special needs can yield better results as some test may not be fair for some learners from cultural diverse backgrounds and type of disabilities.

Some teachers agreed to using portfolios to chronicle the progress of pupils with disabilities. This is in line with Welson and King (1996) who discovered benefits in the use of video tapes, manual projects and assignment to evaluate children with disabilities in their areas of study. Other teachers used oral examination and differentiated spacing in evaluating children with disabilities. This findings are similar to those of (Elliot, Kratoachunill and Schlte 1998) who had earlier found out that performance of students with disabilities increased comparatively when they were tested in a distraction- free room away from their regular peers.

This lack of knowledge of assessment strategies used in inclusive classrooms will to a larger extent affect the grading and promotion of children with special education needs. This can lead to poor performance and eventual drop out especially in the Cameroon educational system where promotion and progress is based on the outcome of test and examinations.

Fuch, (1998) had earlier pointed out the benefits of performance assessment for pupils with special needs, stating specifically that learners constructs their own responses rather than selecting or identifying correct responses, and performance on tasks reflecting realworld situations can reveal their thinking patterns. This falls within the tenets of social constructivism (Ratner, 1991) where man constructs knowledge himself from what he or she has learnt through experience or practice. This calls for diversity in the evaluation strategies used in inclusive classrooms. Similarly, Pelech and Pieper (2010) states that, a good social constructivist teacher views his or her role as one of managing the learning environment and acting as guide, facilitator and coach. Thus there is an urgent need for pre-service and in-service training so as to equip teachers with best assessment strategies in inclusive classrooms.

\section{CONCLUSION}

Assessment is a key factor in the Cameroonian educational system. The system is highly examination-oriented and most times progress and promotion is based on marks/ranks. Since most children with disabilities maybe discouraged and eventually drop out of school if they become stagnant, there is need for the specifications found in the regulations concerning the assessment of children with disabilities to be enforced strictly and not limited only to certificate examinations. Giving the same test to all the children and in the same space/time needs to be greatly discourage in inclusive classrooms. Meanwhile the use of portfolios, practical exercises and other forms of test adaptations should be encouraged.

There is need for teachers to be equipped with skills on how to teach in inclusive classrooms. The trend in literature shows that there are just a few courses in the pre-service teacher training programs in Cameroon geared towards inclusive education. It is imperative that knowledge about children with special education needs and the pedagogic strategies of handling them in classrooms be added in the programs of teacher training institutions so as to impact the necessary skills in the teachers before they go in to service. There is equally need for the Delegations of Basic Education to organize regular seminars where inservice skills can be acquired to address diversity in the classrooms.

Training and recruiting special educators in basic education in Cameroon should be considered seriously. These specialists are highly needed as the children at this stages are still very young and needs more attention which cannot be adequately provided by the regular class teacher alone, coupled with large class sizes.Teachers should be encouraged and supported to increase their knowledge and skills through action research or further studies in higher 
education programs. This will help them to be abreast of the current trends in teaching children with disabilities which will go a long way to increase their efficacy.

\section{REFERENCES}

1. Baca, L. M., and Almanza, E. (1991). Language minority students with disabilities. Reston, VA: Council for Exceptional Children. Law No.83/013 of $21^{\text {st }}$ July 1983 provides general dispositions and practical modalities for the protection of people with disabilities

2. Bowe, F. (2005). Making inclusion work. New York: Merrill Education/Prentice Hall. Bowe, F. (2005). Making inclusion work. New York: Merrill Education/Prentice Hall.

3. Cameroon (2007). Joint circula letter No 283/07/LC/MINSEC/MINAS of August 2007 relating to the identification of disabled children and children born of needy disabled parents. Yaounde: MINSEC/MINAS.

4. Cameroon (1990). Decree No 90/1516 of November 1990 authorizing on age waiver, the right to repeat, remedial classes, exemtion from school fees on financial assistance to disabled children and those born of needy disabled parents. Yaounde: Cameronn.

5. Cameroon (1998). Law No.83/013 of $21^{\text {st }}$ July 1983 provides general dispositions and practical modalities for the protection of people with disabilities. Yaounde: Cameroon

6. Cameroon (2010). Law No.2010/002 of $13^{\text {th }}$ April 2010.Stating the provision of Special education, psychosocial support, socio-economic integration, access to employment and infrastructure, housing and transport for persons with disabilities. Yaounde: Cameroon.

7. Cusher, K. (2006). Human diversity in action. Developing multicultural competences for the classroom. 3rd ed. Boston: McGraw-Hill.

8. EADSNE, (2003). Inclusion education and classroom practice, summary report. Middlefart: European Agency for Development in Special Needs Education middle fort.

9. Elliott, S. N., kratochwill, T. R., and Schutle, A. A. G. (1998). The assessment Cusher, K. (2006). Human diversity in action. Developing multicultural competences for the classroom. 3rd ed. Boston: McGraw-Hill.
10. Accommodation checsclist: Who, what, where, when, why and how? Teaching Exceptional Children, 31,(2), 10-40

11. Endeley, M. N. (2011). Teacher characteristics and attitudes towards inclusive education in Cameroon public secondary schools. Unpublished thesis

12. Endeley, M. N. (2013). Secondary teachers preparayoryprogrammes in Cameroon: perspectives in the implementation of inclusive education. Journal of Special Education 2,1,330345.

13. Erikson, R., Ysseldyke, J., Thurlow, M., and Elliott, J. (1998). Inclusive assessment and accountability system: Tools of the trade in educational reform. Teaching Exceptional Children, 3, (2), 4-9.

14. European Agency for Development in Special Needs Education (EADSNE), (2009). Key Principal for Promotion Quality in Inclusive Education. Recommendation for Policy Denmark: European Agency for Development in Special Needs Education.

15. Farrell, P., and Ainscow, M. (2002). Making special education inclusive: From research to practice. London: David Fulton publishers.

16. Fullan, M. (1999). The new meaning of educational change. London: Cassell Educational ltd.

17. Fuchs, D., and Fuchs, L. S. (1998). Researchers and teachers working together to adopt instruction for diverse learners. Learning Disabilities Research and Practice, 13, 126-137.

18. Gubs, W.N and Lazerson, M. (2004) The education gospel: The economic power of Schooling. Cambridge: Harvard University press.

19. Horton, S., and Lovitt, T. (1994). A comparison of two methods of administering group reading inventories to diverse learners. Remedia and Special Education vol.15. http://www.abdn.ac.uk/eitn/Rouse. pdf. Accessed July 2016.

20. Kurawa, G. (2010). Teaching diversity in a primary school: examining teachers, classroom strategies for inclusion. Procedia Social and Behavioural Science, 5, 1585-1591. Retrieved from Wiley Online Library.

21. Learning Disabilities Association. (1993). Fact sheet: Test of general educational development 
(GED tests). Pittsburgh: Learning Disabilities Association.

22. Lerner, J. (2003). Learning disabilities: Theories diagnosis and teaching Strategies. 9th ed. New York: Houghton Mifflin.

23. Linsay, G. (2007). Educational psychology and the effective on inclusive education/ mainstreaming. British Journal of Educational Psychology, 77, 1-24.

24. Lupart, J. (2002). Meeting the educational needs of exceptional learners in Alberta. Exceptionality Education Canada, 11 (2,3), 55-70.

25. Mastropieri, M. (2000). The inclusive classroom. Strategies for effective instruction. New Jersey: Prentice Hall.

26. Ndame, T. (2012). Whole school inclusion: a case study of two secondary schools in Cameroon. Unpublished thesis. University of Exeter.

27. Nsamenang, A. B., \$ Tchombe, M. S. T. (2011) (Eds). Handbook of African Educational Theories and Practice. A generative teacher education curriculum. Yaounde: Press Universitairesd'Afrique.

28. OECD, (2010). Educating Teachers for Diversity. Meeting the challenge. Paris: OECD.

29. Pelech, J. and Pieper, G. (2010). The Comprehensive Handbook of Constructivist Teaching: From theory to practice. Boston: Information Age.

30. Pijil, S. L., and Frissen, P. H. A. (2009). What policy makers can do to make inclusive education. Educational Management Administration and Leadership, 37, 366-378. Retrieved from Wiley Online Library.

31. Ratner, C. (1991). Vygotsky’s socio-historical psychology and its contemporary applications. New York: Plenum.

32. Raymond, H. (1995). Inclusive education: stories and strategies for success. Ney York: Plenum

33. Salend, S. (1995). Modifying tests for diverse learners. Intervention in School and Clinic, 31, 8490.

34. Scruggs, T. E and Mastropieri M.A. (1996). Teacher perceptions of Mainstreaming-inclusion, 1958-1995. A Research Synthesis. Exceptional Children, 63, 59-74.

35. Shaw, R. and Lewis, V. (2005). The impact of computer-mediated and traditional academic task presentation on the performance and behaviour of children with ADHD. Journal of Research in Special Educational Needs, 5 (2), 47-54.

36. Tchombe, T.M.S et. al (2014). Transnational Research on Inclusive Education in Institution in Africa. The preparedness of educators. The case of Cameroon. Limbe: BUKHUM communication.

37. Toping, K. \& Maloney, S. (2005). The RoutledgeFalmer Reader in Inclusive Education. London: RoutledgeFalmer

38. Tukov, M. (2008). The education of children with special needs in Cameroon. The role of teachers and parents towards inclusive education. Oslo: Department of Education, University of Oslo, Norway.

39. UNSECO, (1985). Helping Handicapped Pupils in Ordinary Schools: Strategies for Teacher training. Paris: UNSECO.

40. UNSECO, (1994). The Salamanca World Conference on Special Needs Education. Access and Quality. Paris: UNSECO and the University of Education, Spain.

41. UNSECO, (2005). Children Out of School: Measuring exclusion from Primary Education. Montreal: UNSECO Institute for Statistics.

42. UNSECO, (2005). Guidelines for inclusion. Ensuring Access to Education for All. Paris UNESCO.

43. UNSECO, (2008). Inclusive Education, the way of the future. International Conference on Education, 48th session. Geneva; 25-28 November.

44. Wolf, J. (2003). The policy, but not the practice of "inclusion." Ney York: GothamGazette.com

45. Ysseidyke, J. E., and Thurlow, M. L. (2000). Critical issues in special education. New York: Houghton Mifflin.

46. Yuh, E. \& Shey, P. (2008). The education of persons with special needs in Cameroon: a historical perspective. African Journal of special Education, 1 (1) 27-31.

47. Venn, J. J. (2000). Assessing students with special needs. 2nd ed. Upper Saddle River NJ: Merill Prentice Hall.

48. Westwood, P. (2007). Commonsense methods for children with special needs. 5th ed. London: Routledge. 